\title{
Rancang Bangun Mesin Pengerolan Pipa 1,5 Inci Menggunakan Motor Listrik Sebagai Penggerak dan Dongkrak 2Ton Sebagai Penekan Pipa
}

\author{
Sirama $^{1 *}$, Simon Parekke ${ }^{2}$ \\ ${ }^{1,2}$ Program Studi Perawatan dan Perbaikan Mesin, Akademi Teknik Soroako \\ ${ }^{1,2} \mathrm{Jln}$. Soemantri Brojonegoro No. 1 Sorowako, Kabupaten Luwu Timur, 92984, Indonesia \\ E-mail: siramasega06@gmail.com ${ }^{1}$, simon@ats-sorowako.ac.id ${ }^{2}$
}

\section{Info Naskah:}

Naskah masuk: 30 Mei 2021

Direvisi: 19 Agustus 2021

Diterima: 24 Agustus 2021

\begin{abstract}
Abstrak
Mesin pengerolan pipa 1,5 inci memanfaatkan tenaga motor listrik sebagai penggerak roda dudukan pipa dan dongkrak 2 ton sebagai penekan pipa. Meskipun mesin rol banyak digunakan pada bengkel-bengkel konvensional dengan menggunakan tenaga manusia menyebabkan waktu pengerolan pipa menjadi lama dan pengguna mesin cepat lelah. Hal ini disebabkan karena kurangnya sumber daya memikirkan pengembangan dan peningkatan kinerja mesin-mesin tersebut. Oleh sebab itu fokus dari penelitian ini adalah rancang bangun mesin pengerolan pipa pipa 1,5 inci menggunakan motor listrik sebagai penggerak dan dongkrak 2 ton sebagai penekan pipa. Penelitian ini bertujuan untuk menghasilkan rancangan dan mesin pengerolan pipa 1,5 inci serta untuk membantu percepatan proses pengerolan pipa dan mengurangi kelelahan pekerja. Mesin pengerol pipa ini terdiri dari beberapa komponen yaitu, rangka mesin, motor listrik, gearbox reducer, chain-sprocket, poros, roda penggerak pipa, pompa hidrolik dan lain sebagainya. Proses kerja mesin ini dimulai dengan menyiapkan pipa 1,5 inci $x 3$ meter kemudian pipa diposisikan di atas roda penggerak, turunkan roda penekan atas sesuai kedalaman yang diinginkan dengan tenaga dongkrak 2ton, hidupkan motor listrik lalu tekan tombol untuk mengerol pipa secara bolak-balik dan seterusnya hingga ukuran pengerolan pipa sesuai kebutuhan. Adapun tahapan dalam pembuatan mesin ini yaitu tahap: perancangan, gambar detail, proses manufaktur, kualiti kontrol, perakitan dan pengujian, pengambilan data dan analisa data. Penelitian menghasilkan gambar rancangan dan pembuatan mesinnya, perhitungan kecepatan putaran mesin untuk pengerolan yang optimal diperoleh $20,46 \mathrm{rpm}$ dan waktu pengerolan pipa rata-rata 6,80 menit untuk satu benda kerja. Mesin ini masih dapat dioptimalisasi dengan menambahkan pembatas gerakan benda kerja saat pengerolan.
\end{abstract}

\section{Keywords:}

Roll machine;

pipe;

electrical motor;

hydraulic jack.

\begin{abstract}
The 1.5inch pipe rolling machine utilizes an electric motor to drive the pipe holder and a 2ton jack as a pipe press. Although the roller machine is widely used in conventional workshops by using human power, it causes the pipe rolling time to be long and the machine user gets tired quickly. This is due to lack of resources to think about developing and improving the performance of these machines. Therefore, the focus of this research is the design of a 1.5inch pipe rolling machine using an electric motor as a drive and a 2 ton jack as a pipe press. This research aims to produce a design and machine for $1.5 \mathrm{inch}$ pipe rolling and to help accelerate the pipe rolling process and reduce worker fatigue. This pipe rolling machine consists of several components, namely, the engine frame, electric motor, gearbox reducer, chain-sprocket, shaft, pipe drive wheel, hydraulic pump and so on. The working process of this machine begins by preparing a $1.5 \mathrm{inch} \times 3$ meter pipe then the pipe is positioned above the drive wheel, lowers the upper pressure wheel to the desired depth with a 2ton jack power, turn on the electric motor and press the button to roll the pipe back and forth and so on. up to pipe roll size as needed. The stages in making this machine are design, detailed drawing, manufacturing process, quality control, assembly and testing, data retrieval and data analysis. The research resulted in drawings of the design and manufacture of the machine, the calculation of the rotational speed of the machine for optimal rolling obtained $20.46 \mathrm{rpm}$ and an average pipe rolling time of 6.80 minutes for one workpiece. This machine can still be optimized by adding a workpiece movement limiter when rolling.
\end{abstract}

*Penulis korespondensi:

Sirama Sega

E-mail: siramasega06@gmail.com 


\section{Pendahuluan}

Besarnya konsumsi penggunaan material baja menjadi sebuah indikator kemajuan suatu negara. Pada umumnya, material baja diaplikasikan pada industri - industri besar seperti industri mesin dan transportasi. Namun, seiring dengan perkembangan jaman, saat ini material baja telah banyak digunakan pada bidang infrastruktur seperti pembuatan kanopi dan ornamen pagar pada bangunan pemukiman. Dalam pembuatan kanopi dan ornamen pagar, material pipa merupakan material yang paling sering digunakan. Dalam proses pengerjaannya, material pipa yang semula berbentuk lurus diubah menjadi bentuk melingkar, setengah melingkar atau kombinasi bentuk dengan variasi radius tertentu. Proses pembentukan ini biasa disebut dengan proses pengerolan. Untuk melakukan proses tersebut, dibutuhkan alat bantu khusus yang disebut mesin pengerol pipa[1].

Perkembangan jaman yang serba otomatis maka dituntut untuk menghasilkan produk dengan cepat dan tepat terkhusus di bidang industri. Sumber daya yang ada perlu memiliki skill atau keahlian dibidang tertentu agar dapat memposisikan di era industri 4.0. Di era seseorang dituntut untuk lebih aktif dan kreatif serta memiliki daya inovasi. Guna tercapainya tujuan tersebut maka diperlukan suatu model atau rancangan mesin yang baik[2]. Kualitas produk yang diproduksi merupakan salah satu indikator yang menentukan apakah produk tersebut layak atau tidak. Produk yang tidak memiliki kecatatan dalam produksi serta sesuai dengan permintaan konsumen merupakan produk yang berkualitas[3].

Beberapa peneliti lain juga menyatakan hasil penelitiannya baik dari segi perancangan, mesin pengerolan pipa, motor listrik yang digunakan maupun dongkrak sebagai penekan pipa, diantaranya, bahwa Perancangan (design) mesin didefinisikan suatu kegiatan perancangan sebuah mesin dalam sebuah gambaran atau sketsa komponen-komponen menjadi sebuah mesin yang berfungsi, yang kemudian hasil sketsa tersebut dianalisa untuk menentukan bagaimana langkah kerja untuk penyelesaian rancangan tersebut[4]. Dalam merancang penting juga memperhatikan bahwa semakin besar jarak pembengkokan waktu yang diperlukan untuk membentuk semakin singkat dan semakin kecil jarak pembengkokan waktu yang diperlukan untuk membentuk sudut semakin tinggi[5], sedangkan penentuan besarnya gaya pembengkokan yang diperlukan tergantung pada besarnya tegangan pembengkokan dari material pipa yang akan dibentuk dan jarak tumpuan antar rol[6].

Salah satu referensi dalam penelitian ini adalah rancang bangun mesin rol pembengkokan pipa evaporator freezer kapal dengan motor listrik $1 \mathrm{hp}$ dengan Sistem transmisi yang digunakan adalah gearbox dan vanbelt. Gearbox yang digunakan ada 2 buah, menggunakan daya motor listrik sebesar $1 \mathrm{HP}$ dengan kecepatan $1450 \mathrm{rpm}$. Menggunakan reducer untuk mereduksi putaran dan dilanjutkan ke gearbox dengan perbandingan 1:40 dan gearbox 1:100[7]. Sedangkan untuk penekanan pipa menggunakan dongkrak yang berfungsi sebagai alat bantu alat penekan atau pengangkat beban. Dongkrak akan sangat membantu dan mempermudah manusia untuk mengangkat beban untuk jangka waktu lama dengan beban yang tidak mampu ditekan atau diangkat oleh manusia[8].

Untuk mengatasi permasalah tersebut di atas maka penelitian ini diharapkan dapat memunculkan kreativitas dan inovasi baru untuk menghasilkan mesin atau peralatan tepat guna yang bermanfaat bagi masyarakat dalam membantu mempecepat proses pekerjaan, meningkatkan produktivitas, dan menurunkan biaya produksi sehingga harga produk dapat bersaing di pasaran, sehingga dapat memenuhi kebutuhan konsumen[9].

Tujuan penelitian ini adalah rancang bangun mesin pengerolan pipa 1,5inci menggunakan motor listrik sebagai penggerak dan dongkrak 2ton sebagai penekan pipa serta mempercepat proses perolingan pipa. Rancang bangun ini diharapkan menjadi rekomendasi pengembangan penelitian selanjutnya.

\section{Metode}

Tahapan penelitian yang dilakukan diperlihatkan pada Gambar 1, merupakan diagram alir penelitian dimulai dari studi literatur, perencanaan mesin, proses manufaktur, kualiti kontrol, pengujian mesin, pengambilan data, Analisa data, kesimpulan dan selesai.

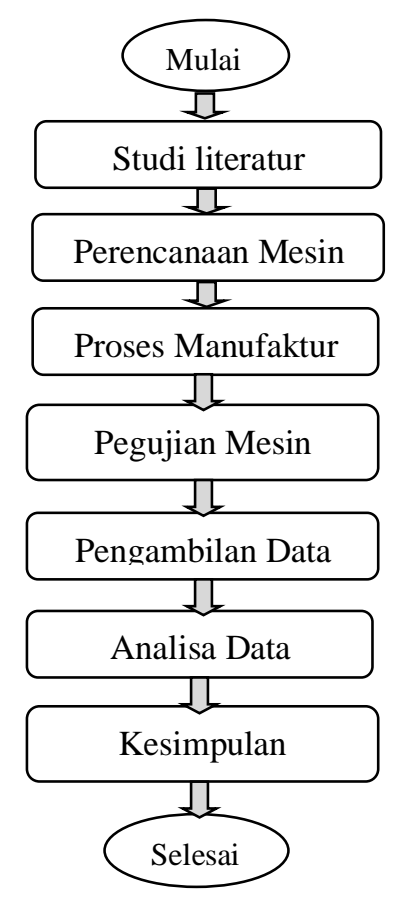

Gambar 1. Diagram Alir Penelitian

\subsection{Perancangan Mesin}

Perancangan mesin didefinisikan sebagai suatu kegiatan perancangan mesin yang menjadi gambaran atau sketsa komponen-komponen mesin yang berfungsi, yang kemudian hasil sketsa tersebut dianalisa untuk menentukan bagaimana langkah kerja untuk penyelesaian rancangan tersebut[7]. Perancangan produk itu sendiri terdiri dari serangkaian kegiatan yang berurutan, karena itu perancangan kemudian disebut sebagai proses yang mencakup seluruh kegiatan yang terdapat dalam 
perancangan tersebut[10]. Tahapan perancangan ditunjukkan pada gambar 2 .

\subsection{Tahapan Perancangan}

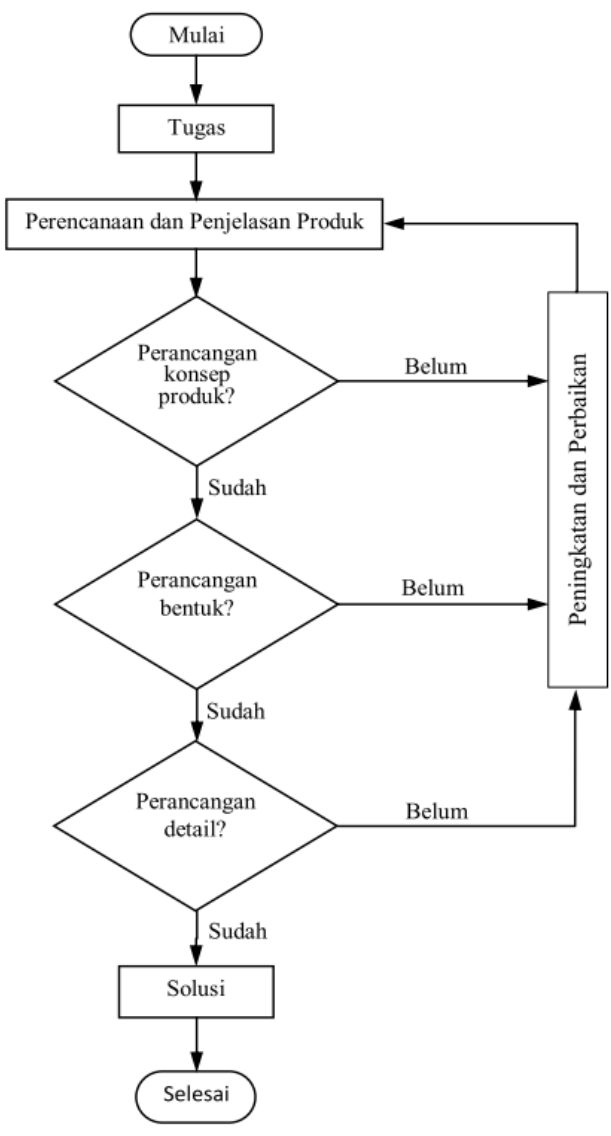

Gambar 2. Tahapan perancangan produk/mesin

\section{a) Tahap perencanaan dan penjelasan mesin}

Tahap ini meliputi pengumpulan informasi permasalahan yang dihadapi, selanjutkan persyaratan mengenai sifat dan performa tuntutan mesin yang harus dimiliki untuk mendapatkan solusi. Pada mesin pengerol pipa ini biasanya di bengkel-bengkel menengah ke bawah masih menggunakan pengerolan yang sederhana secara manual. Terutama penggerak utamanya masih menggunakan tenaga manusia, untuk itu diperlukan mesin yang praktis dengan harga yang ekonomis serta efektif[9].

\section{b) Tahap perancangan konsep mesin}

Solusi alternatif konsep mesin selanjutnya dievaluasi berdasarkan persyaratan teknis, ekonomis, dan lain-lain. Tahapan ini dapat diawali dengan mengenal dan menganalisis spesifikasi mesin yang telah ada. Hasil analisis spesifikasi produk dilanjutkan dengan memetakan struktur fungsi komponen sehingga dapat disimpulkan beberapa alternatif solusi pemecahan masalah konsep mesin. Tahapan ini ditunjukkan pada butir 2.3 pemilihan alternatif komponen, pada tabel 1 dan 2 tentang penilaian komponen mesinnya serta tabel 3 tentang komponen terpilih.

\section{c) Tahap perancangan bentuk mesin}

Perancangan bentuk memerlukan beberapa pertimbangan untuk menentukan solusi setiap proses perencanaan. Berdasarkan kasus masalah yang dihadapi yaitu perencanaaan mesin pengerol pipa, pendekatan konsep yang digunakan adalah dengan perencanaan simultan atau perencanaan dengan pendekatan proses produksi. Konsep perencanaan simultan terdapat empat elemen utama, yaitu: fungsi, bentuk, material, dan produksi.

\section{d) Tahap perancangan rinci/detail}

Perancangan rinci merupakan hasil keputusan perencanaan berdasarkan beberapa tahapan sebelumnya. Luaran dari tahapan ini adalah gambar rancangan rinci dan spesifikasi mesin untuk pembuatan yang biasa disebut dokumen pembuatan mesin. Sebagai konsep utama perancangan metode tersebut, bahwa hasil setiap tahapan dapat berubah setiap saat berdasarkan umpan balik yang diterima dari hasil tahapan- tahapan berikutnya.

\section{e) Tahap solusi rancangan terpilih}

Dari alternatif rancangan yang ditawarkan dengan membandingkan kelebihan serta kekurangan dari masingmasing desain maka dipilih desain sebagai alternatif terbaik. Artinya desain alternatif memiliki nilai tertinggi dari penilaian yang telah ditentukan, sehingga dipilih sebagai rancangan yang akan digunakan. Perancangan rinci merupakan hasil keputusan perencanaan berdasarkan beberapa tahapan sebelumnya. Luaran dari tahapan ini adalah gambar rancangan rinci dan spesifikasi mesin untuk pembuatan yang biasa disebut dokumen pembuatan mesin. Gambar rancangan alternatif terpilih terlihat pada gambar 3 dan gambar susunan ditunjukkan pada gambar 4 .

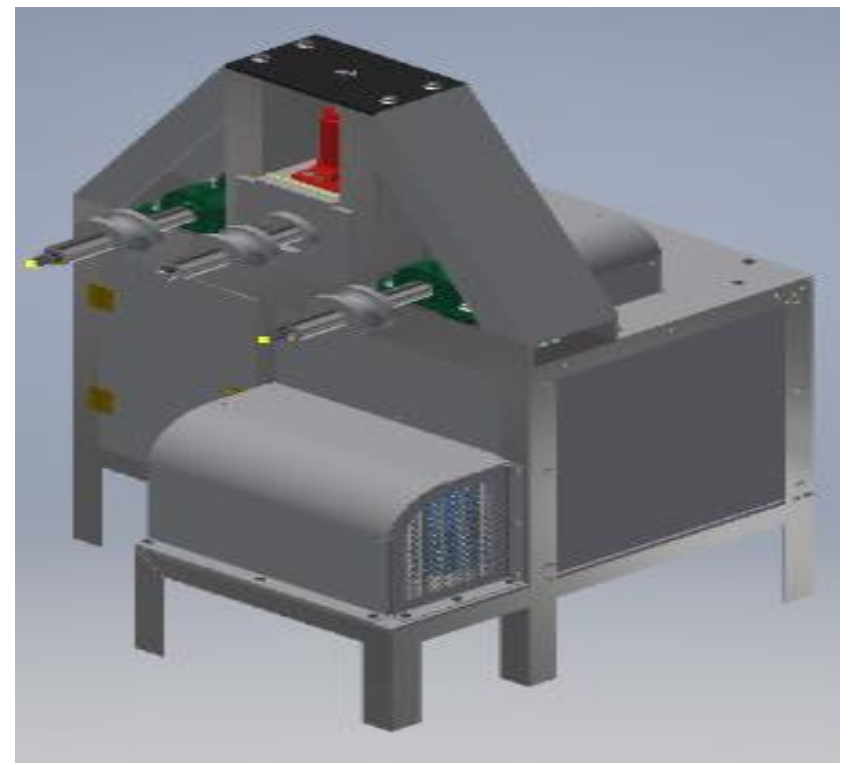

Gambar 3. Gambar rancangan alternatif mesin 
Tabel 1. Daftar tuntutan dan penilaian komponen alternatif

\begin{tabular}{|c|c|c|c|c|c|c|c|c|c|c|c|c|c|}
\hline \multirow{3}{*}{ NO } & \multirow{3}{*}{ Tuntutan } & \multicolumn{12}{|c|}{ PENILAIAN } \\
\hline & & \multicolumn{3}{|c|}{ Poros } & \multicolumn{3}{|c|}{ Roller } & \multicolumn{3}{|c|}{ Landasan poros } & \multicolumn{3}{|c|}{ Penekan } \\
\hline & & & & & & & & & & & & & 1 \\
\hline 1 & Harga Bahan & 4 & 4 & 4 & 4 & 4 & 3 & 3 & 4 & 3 & 5 & 3 & 4 \\
\hline 2 & $\begin{array}{l}\text { Ketersediaan } \\
\text { Bahan } \\
\text { Pembuatan }\end{array}$ & 4 & 4 & 4 & 4 & 4 & 4 & 4 & 4 & 4 & 4 & 3 & 4 \\
\hline 3 & $\begin{array}{l}\text { Bagian/ } \\
\text { Komponen }\end{array}$ & 4 & 4 & 3 & 3 & 4 & 3 & 3 & 3 & 5 & 4 & 4 & 4 \\
\hline 4 & Pengoperasian & 5 & 4 & 3 & 3 & 5 & 3 & 4 & 3 & 4 & 3 & 5 & 4 \\
\hline 5 & Perakitan & 4 & 4 & 4 & 4 & 5 & 3 & 4 & 3 & 4 & 3 & 4 & 5 \\
\hline 6 & Perawatan & 4 & 4 & 3 & 4 & 4 & 3 & 4 & 4 & 4 & 3 & 3 & 4 \\
\hline 7 & Estetika & 5 & 3 & 4 & 4 & 5 & 4 & 4 & 3 & 5 & 3 & 5 & 4 \\
\hline 8 & Ergonomis & 5 & 4 & 4 & 4 & 4 & 4 & 4 & 3 & 5 & 3 & 4 & 4 \\
\hline & Total & 35 & 31 & 29 & 30 & 35 & 27 & 30 & 27 & 34 & 28 & 31 & 33 \\
\hline
\end{tabular}

Tabel 2. Daftar tuntutan dan penilaian komponen alternatif (lanjutan)

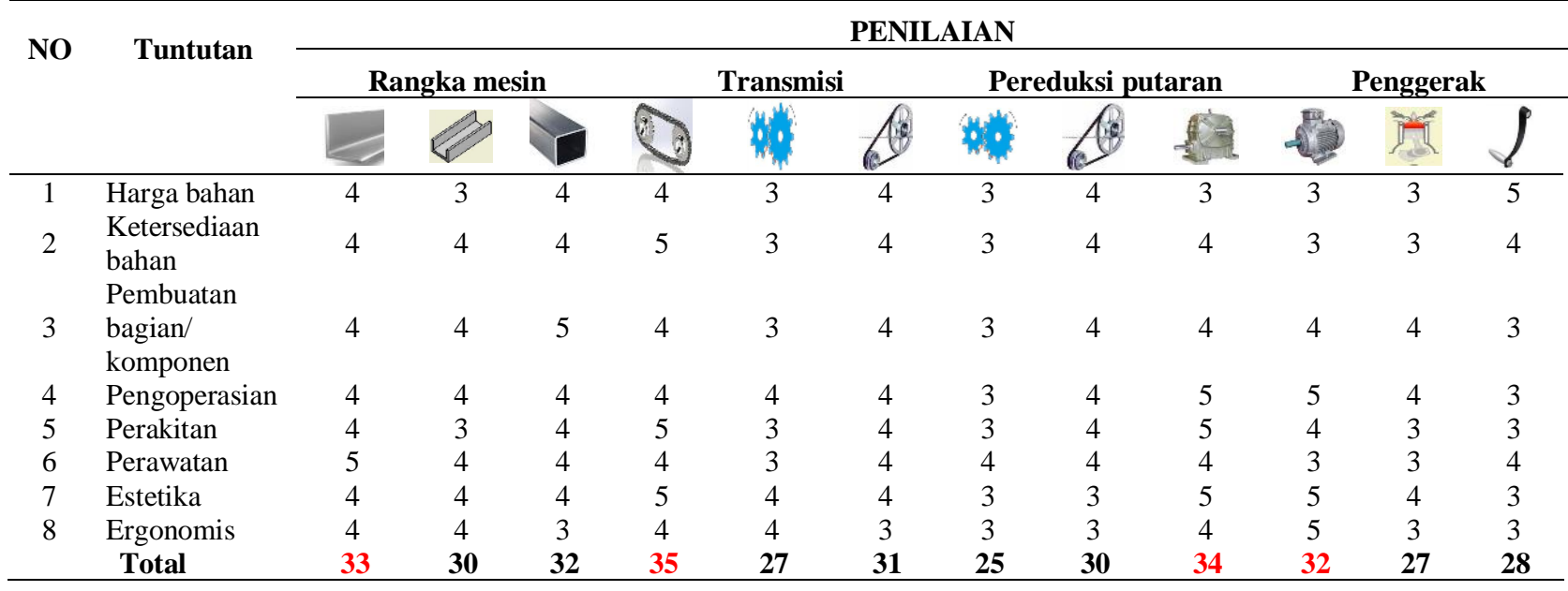
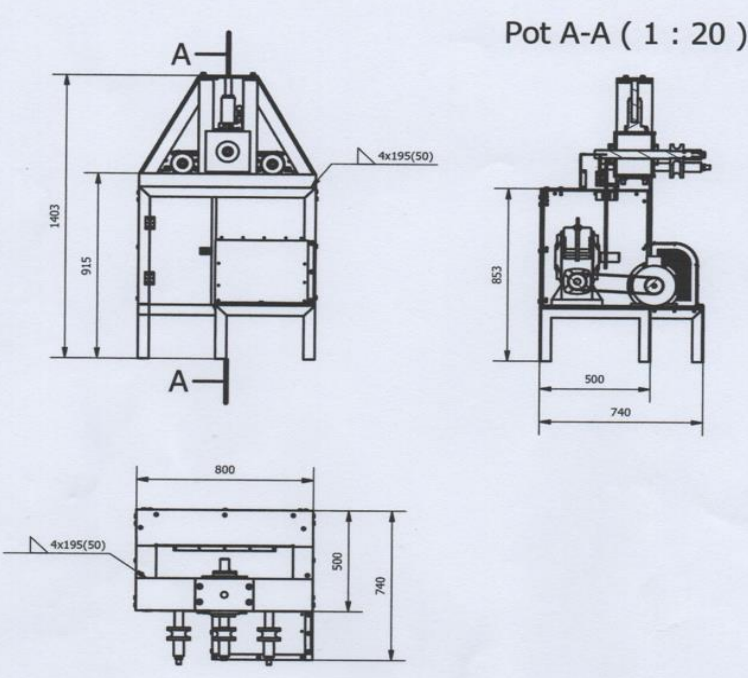

Gambar 4. Gambar susunan mesin

\subsection{Pemilihan Alternatif Komponen}

Pada Tabel 1 dan Tabel 2 menunjukkan daftar tuntutan dan penilaian alternatif komponen, komponen alternatif yang menghasilkan nilai tertinggi (berwarna merah) akan terpilih sebagai komponen yang akan menjadi salah satu bagian dari mesin rol yang akan dibuat. Komponen terpilih setelah dilakukan penilaian alternatif, seperti diperlihatkan pada Tabel 3.

\section{Hasil dan Pembahasan}

Hasil rancangan dan pembuatan mesin pengerolan menggunakan tenaga motor listrik $1 \mathrm{Hp}$ dengan putran 1400rpm dan penekan pipa diameter 1,5 inci menggunakan dongkrak 2ton terlihat pada Gambar 5.

\subsection{Prinsip Kerja Mesin}

Mesin ini dirancang dan dibuat untuk perolingan pipa dengan daya penggerak menggunakan motor listrik 1HP yang memiliki putaran $1400 \mathrm{rpm}$. Motor listrik berfungsi untuk memutar poros tetap dengan cara mentransmisikan daya ke poros utama melalui puli dan sabuk kemudian diteruskan oleh rantai dan roda gigi rantai[11]. Adapun 
prinsip kerja dari mesin rolling ini sebagai berikut: pipa diletakkan pada kedua poros tetap, kemudian poros penekan diturunkan hingga menyentuh pipa yang akan dirolling, posisi awal pipa sebelum proses pengerollan berada di atas roller proros tetap, saat motor dihidupkan, maka putaran motor akan ditransmisikan ke puli \& sabuk yang terhubung dengan reducer, kemudian dari reducer akan ditransmisikan ke poros tetap melalui rantai dan roda gigi rantai dan pada saat berputar maka roller akan ikut berputar membawa pipa sehingga terjadilah pengerollan berputar ke kanan dan ke kiri yang dikontrol oleh tombol pembatas gerakan.

Tabel 3. Daftar komponen terpilih

\begin{tabular}{|c|c|c|}
\hline No & Komponen & Altrenatif Terpilih \\
\hline 1. & Poros penekan & \\
\hline 2. & $\begin{array}{l}\text { Roda } \\
\text { penggerak }\end{array}$ & \\
\hline 3. & $\begin{array}{l}\text { Landasan } \\
\text { poros (profil- } \\
\text { U) }\end{array}$ & \\
\hline 4. & $\begin{array}{l}\text { Dongkrak } \\
2 \text { ton } \\
\text { (Penekan) }\end{array}$ & \\
\hline 5. & $\begin{array}{l}\text { Rangka mesin } \\
\text { (besi siku) }\end{array}$ & \\
\hline 6. & $\begin{array}{l}\text { Chain- } \\
\text { sprocket }\end{array}$ & \\
\hline 7. & $\begin{array}{l}\text { Pereduksi } \\
\text { putaran } \\
\text { (reducer) }\end{array}$ & \\
\hline 8. & Motor listrik & \\
\hline
\end{tabular}

\subsection{Diagram gaya pada roda penggerak}

Gambar 6 di bawah adalah gambar diagram gaya yang terjadi pada roda penggerak dan penekan pipa. Gambar 7 menunjukkan gaya tekan pada pipa dan besar gaya penekanan pipa yang dibutuhkan dapat dilihat menggunakan persamaan (3) dan dimensi pipa terlihat pada Gambar 8 .
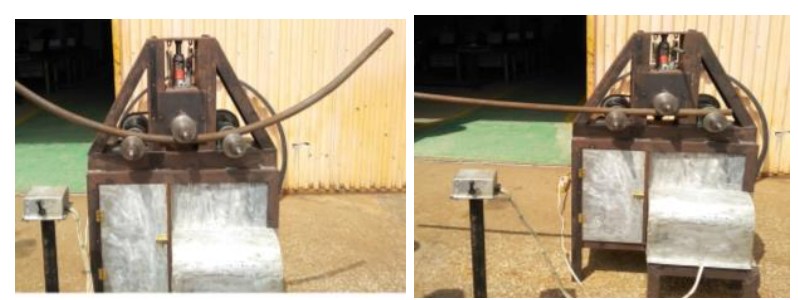

Gambar 5. Mesin pengerol pipa
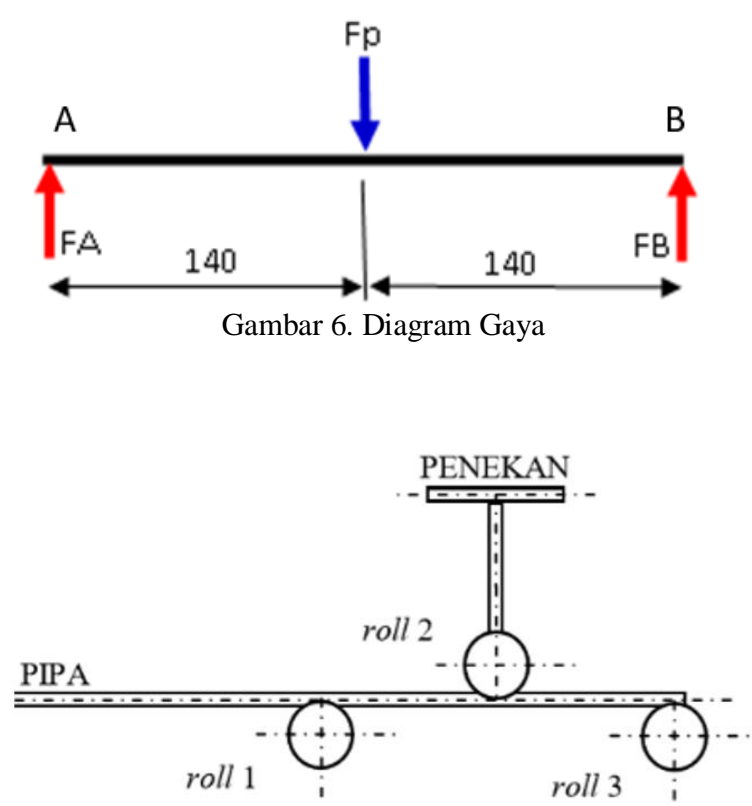

Gambar 7. Roda penekan pipa [4]

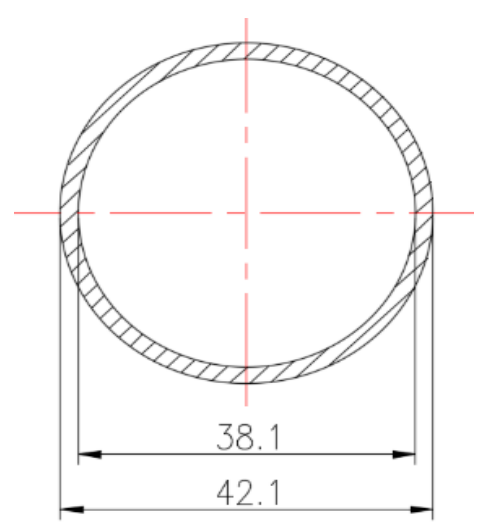

Gambar 8. Material pipa

Gaya penekanan pada pipa dapat dihitung melalui rumus (1) tegangan bengkok.

$$
\begin{aligned}
\sigma \mathrm{b}_{\max } & =\mathrm{M}_{\mathrm{b}} / \mathrm{W}_{\mathrm{b}} \\
\sigma \mathrm{b}_{\mathrm{iz}} & =\frac{F d \cdot l}{\frac{D^{4}-d^{4}}{D} \times \frac{\pi}{32}} \\
\mathrm{Fp} & =\left(\mathrm{D}^{4}-\mathrm{d}^{4}\right) \cdot \pi /(1 \cdot D \cdot 32)
\end{aligned}
$$

$\left(\mathrm{N} / \mathrm{mm}^{2}\right)(1)$ 
Maka hasil dari gaya penekanan pipa tersebut dihitung dengan cara sebagai berikut:

$$
\begin{aligned}
& \mathrm{D}=42,1 \mathrm{~mm} \quad \text { (diameter luar pipa) } \\
& \mathrm{d}=38,1 \mathrm{~mm} \quad \text { (diameter dalam pipa) } \\
& \sigma \mathrm{b}_{\mathrm{iz}}=120 \mathrm{~N} / \mathrm{mm}^{2} \text { (tegangan bengkok ijin pipa) }
\end{aligned}
$$

Penyelesaian :

$$
\begin{aligned}
\sigma \mathrm{b}_{\max } & =\frac{M b}{W b} \\
\sigma \mathrm{b}_{\mathrm{iz}} & =\frac{F d \cdot l}{\frac{D^{4}-d^{4}}{D} \times \frac{\pi}{32}} \\
& =\frac{F d \cdot 140}{\frac{42,1^{4}-38,1^{4}}{42,1} \times \frac{\pi}{3}} \\
120 & =\frac{F d \cdot 140}{2411,84} \\
\mathrm{Fd} & =\frac{120.2411,84}{140} \\
& =\frac{120.2411,84}{140} \\
& =2067,29 \mathrm{~N}
\end{aligned}
$$

Perancangan poros dudukan roda penggerak perlu memperhatikan dan memperhitungkan dapat kekuatannya dengan rumus (4) - (7) [14].

$$
\begin{array}{rlrl}
\tau p & =\mathrm{Mp} / \mathrm{Wp} & & \left(\mathrm{N} / \mathrm{mm}^{2}\right) \\
\mathrm{Mp}_{1} & =9550 . \mathrm{P} . \mathrm{CB} / \mathrm{n} & & (\mathrm{Nmm}) \\
& =9550.745,7.1 / 3600 & \\
& =1978,1 & & (\mathrm{~N} \mathrm{~mm}) \\
\mathrm{Mp} 2 & =\mathrm{Mp} 1 \times \mathrm{i} & & (\mathrm{Nmm}) \\
& =1978,1 \times 40 & \\
& =79127,05 \mathrm{Nmm} & \\
\tau \text { p } & =\frac{M p_{2}}{W p} & \\
& =\frac{79127,05}{\frac{d^{3}}{5}} & & \left(\mathrm{~N} / \mathrm{mm}^{2}\right) \\
& =\frac{79127,05}{\frac{40^{3}}{5}} & \\
& =6,181 & \\
\tau \text { piz } & =140 & & \left(\mathrm{~N} / \mathrm{mm}^{2}\right) \\
& & \left(\mathrm{N} / \mathrm{mm}^{2}\right)
\end{array}
$$

Karena $\tau_{\mathrm{p}}<\tau_{\mathrm{p}}$ iz maka poros aman terhadap puntiran.

a) Kekuatan bengkok poros penekan

Untuk mengetahui kekuatan bengkok poros penekan menggunakan rumus (8).

$$
\begin{aligned}
\sigma \mathrm{b} & =\frac{M b}{W b} \quad\left(\mathrm{~N} / \mathrm{mm}^{2}\right) \\
& =\frac{529951,95}{0,1 \cdot d^{3}} \\
& =\frac{529951,95}{0,1 \cdot 40^{3}}
\end{aligned}
$$

$$
\begin{aligned}
& =82,80 \\
& \text { Tbiz }=120 \\
& \left(\mathrm{~N} / \mathrm{mm}^{2}\right) \\
& \left(\mathrm{N} / \mathrm{mm}^{2}\right) \\
& \sigma b<\sigma b_{i z} \text { maka poros penekan aman. }
\end{aligned}
$$

Untuk menghitung Daya motor listrik, diperolah dengan melalui perhitungan sebagai berikut:

$$
\begin{aligned}
& \mathrm{Mp}=1978,1(\mathrm{~N} \mathrm{~mm}) \text { (momen puntir motor) } \\
& \mathrm{CB}=1 \text { (faktor pemakaian) } \\
& \mathrm{P} \quad=\text { daya motor listrik (watt) } \\
& \mathrm{n} \quad=3600 \mathrm{rpm} \text { (putaran motor listrik) } \\
& \begin{aligned}
\mathrm{Mp} & =9550(\text { CB.P }) / \mathrm{n} \\
\mathrm{P} & =\mathrm{Mp} . \mathrm{n} / 9550 . \mathrm{CB} \\
& =1978,1.3600 / 9550.1 \\
& =745,67 \text { Watt }
\end{aligned}
\end{aligned}
$$

Hasil output putaran reducer dan Putaran poros penggerak diperoleh dengan cara menghitung sebagai berikut:

$$
\begin{array}{ll}
\text { Putaran motor listrik } & =1400 \mathrm{rpm} \\
\text { Reducer ratio } & =1: 60 \\
\text { Sprocket reducer } & =35 \text { gigi } \\
\text { Sprocket } \text { poros } & =40 \text { gigi } \\
\text { sprocket reducer }: \text { poros }=1: 1,14
\end{array}
$$

menghasilkan Output reducer

$$
\frac{1400}{1} \times \frac{1}{60}=23.33 \mathrm{rpm}
$$

Menghasilkan Output poros penggerak

$$
\frac{23.33}{1} \times \frac{1}{1.14}=20.46 \mathrm{rpm}
$$

\subsection{Pengujian Pengerolan Pipa}

Pada tabel 4 dan gambar 9 merupakan hasil pengujian pipa yang telah dilakukan, terlihat bahwa semakin dalam penekanan pipa semakin lama waktu yang dibutuhkan untuk proses pengerolan.

Tabel 4. Data Pengujian Profil Pipa 1,5 inci

\begin{tabular}{ccc}
\hline No & $\begin{array}{c}\text { Kedalaman } \\
\text { Penekanan }(\mathbf{m m})\end{array}$ & $\begin{array}{c}\text { Waktu Proses } \\
(\text { menit })\end{array}$ \\
\hline 1 & 2 & 1,05 \\
2 & 4 & 3,17 \\
3 & 6 & 6,02 \\
4 & 8 & 10,27 \\
5 & 10 & 13,30 \\
Rata $^{2}$ & 6 & 6,76 \\
\hline
\end{tabular}




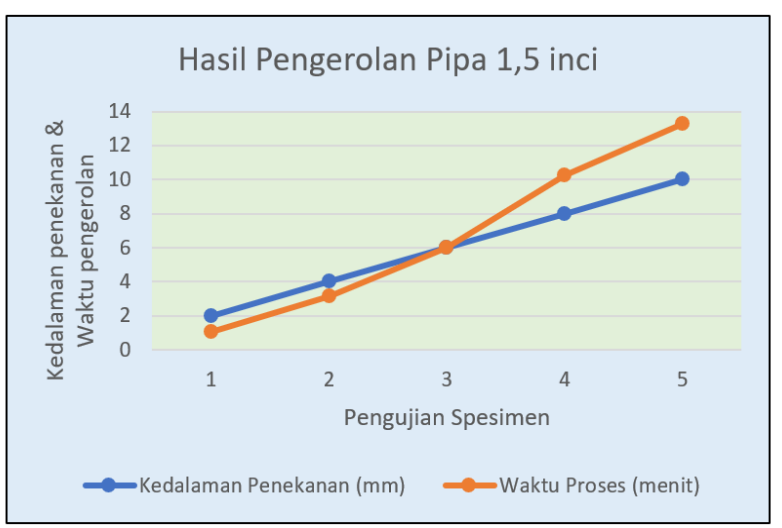

Gambar 9. Kedalaman \& Waktu Pengerolan Pipa

\section{Kesimpulan}

Berdasarkan hasil dan pembahasan dari penelitian ini telah menghasilkan rancangan dan gambar kerja pembuatan mesin roll pipa 1,5inci menggunakan motor listrik $1 \mathrm{HP}$, $1400 \mathrm{rpm}$ sebagai penggerak dan dongkrak 2ton sebagai penekan pipa, Dimensi mesin pengerol pipa secara keseluruhan adalah $800 \mathrm{~mm}$ x $740 \mathrm{~mm}$ x $1400 \mathrm{~mm}$ dengan rangka mesin terbuat dari bahan baja St.37, sedangkan hasil pengujian mesin menunjukkan bahwa semakin dalam penekanan pipa maka waktu yang dibutuhkan untuk pengerolan akan semakin lama dimana rata-rata waktu yang dibutuhkan adalah 6,76 menit dengan Panjang pipa 3meter hingga membentuk setengah lingkaran.

Penelitian ini diharapkan dapat memberi manfaat kepada masyarakat dalam meningkatkan produktivitas, kinerja dan waktu proses perolingan pipa sehingga mapu bersaing di pasaran [12] dan pekerja tidak cepat lelah atau capek. Penelitian ini juga masih berpotensi dikembangkan dalam hal pemasangan sensor pembatas gerakan pengerolan pipa.

\section{Ucapan Terimakasih}

Terima kasih penulis ucapkan kepada semua pihak yang telah memberikan bantuan dalam proses penyelesaian penelitian ini baik itu dari biaya penelitian, sumbang saran atau ide maupun dukungan lainnya.

\section{Daftar Pustaka}

[1] P. Alat and P. Pipa, "Perancangan alat pengerol pipa 1 1/4 inchi dengan pengoperasian manual dan sistem hidrolik," vol. 11, no. 2, pp. 62-71, 2019.

[2] A. Saleh, S. Alamsyah, A. Saleh, and T. Mesin, "Perancangan sistem kontrol plc pada mesin bending rol pipa," vol. 13, no. 3, pp. 228-232, 2019.

[3] U. Tarigan, R. Ginting, and W. S. Sarah, "Pendekatan Metode DFMA ( Design for Manufacture and Assembly ) TALENTA Conference Series Pendekatan Metode DFMA ( Design for Manufacture and Assembly ) Pada Perancangan Produk Matras," vol. 3, no. 2, 2020, doi: 10.32734/ee.v3i2.1041.

[4] A. Tangkemanda, A. H. Rasak, F. Febriyanto, F. Renaldy, and M. Erfin, "Rancang Bangun Mesin Rol Bending Pipa Besi," J. Tek. Mesin Sinergi, vol. 19, no. 1, p. 97, 2021, doi: 10.31963/sinergi.v19i1.2764.

[5] E. Umbu, T. Marisi, B. Masalah, D. M. Mesin, and R. Masalah, "Analisa Proses Pengerolan Pipa Dengan Menggunakan,” vol. 2, pp. 837-846, 2012.

[6] F. Lengkung, "Analisis proses pengerolan pipa dengan," pp. 639-648, 2011.

[7] S. Sunarto, S. Sisworo, and A. Z. Prasojo, "Rancang Bangun Mesin Roll Bending Pipa Evaporator Freezer Kapal Dengan Motor Listrik 1 HP," J. Rekayasa Mesin, vol. 13, no. 3, p. 105, 2018, doi: 10.32497/rm.v13i3.1280.

[8] C. Sutowo, "Analisis Dongkrak Ulir Dengan Beban 4000 Kg,” pp. 1-10, 2009.

[9] A. Mustakim, "Rancang Alat/Mesin Pengerol Pipa," p. 32 ، 2012, ص ص.

[10] R. Ginting and M. Khatami, "PAPER - OPEN ACCESS Perancangan Produk dengan Menggunakan Nigel Cross TALENTA Conference Series Perancangan Produk dengan Menggunakan Nigel Cross," vol. 2, no. 3, 2019, doi: 10.32734/ee.v2i3.730.

[11] T. Mesin and P. Harapan, "Issn : 2087-1627," vol. 9, no. 1, pp. 47-52, 2018.

[12] J. T. Mesin, F. Teknik, U. M. Malang, and A. Situasi, "IbM Bengkel Las Teknik Dalam Upaya Peningkatan Kualitas Rectangular Pipe Bending Process Dengan Desain Flexible Roll," no. September, 2019. 